\title{
EVALUASI TERHADAP KEMAMPUAN KADER KESEHATAN DALAM MELAKUKAN KEGIATAN PENJANGKAUAN
}

\author{
EVALUATION FOR ABILITY OF HEALTH CADRE \\ IN OUTREACH ACTIVITY
}

\author{
Nur Ulfah, Budi Aji dan Siti Harwanti \\ Jurusan Kesehatan Masyarakat Fakultas Ilmu-Ilmu Kesehatan \\ Universitas Jenderal Soedirman
}

\begin{abstract}
ABSTRAK
Kecelakaan kerja pada tappers kelapa sawit dapat terjadi karena keadaan berbahaya (unsafe codition) dan tindakan tidak aman (tindakan tidak aman). Upaya untuk mencegah perilaku tidak aman diperlukan untuk mengurangi risiko kecelakaan tersebut dengan pendekatan manusia, yaitu kader kesehatan. Peran kader kesehatan dalam hal ini adalah untuk memberikan informasi kepada para penyok tapak pengaman keselamatan. Sementara kemampuan kader bisa ditingkatkan melalui program mentoring. Penelitian ini merupakan percobaan kuasi tanpa perbandingan. Sampel dalam penelitian ini adalah petugas kesehatan di Desa Pageraji, Langgongsari, dan Rancamaya Kecamatan Cilongok Kabupaten Banyumas sebanyak 30 orang. Instrumen penelitiannya adalah kuesioner dan daftar periksa. Analisis data untuk melihat perbedaan pretest dan posttest menggunakan uji Wilcoxon. Hasil analisis statistik Uji Wilcoxon menunjukkan adanya peningkatan pengetahuan, sikap dan keterampilan secara signifikan setelah mendapat bantuan, dengan hasil nilai pengetahuan $\mathrm{p}=0,04<\alpha(0,05)$, hasil analisis terhadap sikap nilai $\mathrm{p}=0.00<\alpha$ $(0,05)$, hasil analisis keterampilan $\mathrm{p}=0,00<\alpha(0,05)$. Ada peningkatan pengetahuan, sikap dan keterampilan secara signifikan setelah mentoring.

Kata kunci: Evaluasi, Kemampuan, Penjangkauan
\end{abstract}

\begin{abstract}
Work accident on palm tappers can occur due to a dangerous state (unsafe codition) and unsafe acts (unsafe action). Efforts to prevent unsafe behaviors necessary to reduce the risk of such accidents with human approach, that of health cadres. The role of health cadres in this regard is to provide information to the safety behavior palm tappers. Meanwhile, cadres ability can be improved through a mentoring program. This research is a Quasi Experiment without comparison. The sample in this study is a health worker in the village Pageraji, Langgongsari, and RancamayaCilongok District of Banyumas regency as many as 30 people. The research instrument was a questionnaire and checklist. Data analysis to look at differences in pretest and posttest using the Wilcoxon test. Results of statistical analysis Wilcoxon test showed an increase of knowledge, attitudes and skills significantly after assistance, with the results of the knowledge value of $\mathrm{p}=$ $0.04<\alpha(0.05)$, the results of the analysis of the attitude of the value of $p=0.00<\alpha(0,05)$, the results of the analysis of skills $p=0.00<\alpha(0.05)$. There is an increased knowledge, attitudes and skills significantly after mentoring.

Keywords: Evaluation, Ability, Outrich

\section{PENDAHULUAN}

Keselamatan dan kesehatan

kerja (K3) merupakan suatu upaya

untuk menciptakan tempat kerja

yang aman, sehat, bebas dari

kecelakaan kerja dan penyakit akibat

kerja yang pada akhirnya dapat

meningkatkan efisiensi dan

produktivitas kerja (Departemen

Kesehatan, 2009). Keselamatan
\end{abstract}


penting diterapkan baik pada pekerja sektor formal atau informal guna mengurangi kecelakaan kerja dan penyakit akibat kerja (PAK) (Muhammad, 2010).

Kecelakaan kerja informal dapat terjadi karena keadaan yang berbahaya (unsafe codition) dan tindakan yang tidak aman (unsafe action). Penderes kelapa merupakan kelompok kerja informal yang berisiko terhadap kecelakaan kerja. Risiko kerja bagi penderes kelapa antara lain kecelakaan kerja yang menimbulkan kecacatan ringan, sedang, dan berat hingga menyebabkan kematian. Hal ini dibuktikan dengan hasil penelitian Aji dkk (2015), bahwa khususnya di tiga desa Kecamatan Cilongok yaitu desa Rancamaya, Pageraji dan Langgongsari terdapat kecelakaan kerja pada penderes sebanyak 94 orang (89,5\%), dimana dari 94 orang tersebut sebanyak 2 orang $(1,9 \%)$ jatuh dari pohon kelapa, 66 orang $(62,9 \%)$ terpeleset, dan 26 orang $(24,8 \%)$ lainnya tergores dan tersiram air gula panas. Perilaku tidak aman merupakan faktor utama penyebab terjadinya kecelakaan kerja akibat kelalaian pekerja saat bekerja (Shiddiq, 2013).

Upaya pencegahan perilaku tidak aman diperlukan untuk mengurangi risiko terjadinya kecelakaan kerja dan penyakit akibat kerja diantaranya dengan pendekatan manusia untuk meningkatkan pengetahuan dan keterampilan sehingga kesadaran Keselamatan dan Kesehatan Kerja (K3) meningkat (Ramli, 2009). Pendekatan manusia dapat dilakukan dengan pendekatan dari kader kesehatan. Peran kader kesehatan yaitu sebagai promotor kesehatan yang bertugas mengembangkan masyarakat. Peran kader kesehatan dalam hal ini yaitu memberikan informasi safety behavior kepada penderes kelapa. Sedangkan, kemampuan kader dapat ditingkatkan melalui program pendampingan. Notoatmodjo (2003) menyebutkan bahwa pendampingan adalah upaya untuk menyertakan diri dan masyarakat dalam memantau dan membangun potensi yang dimiliki orang lain menuju pencapaian kualitas hidup yang lebih baik. Hasil penelitian Utami (2011) bahwa Pengetahuan, Sikap, dan 
Keterampilan Kader kesehatan dapat ditingkatkan melalui pendampingan.

Berdasarkan uraian di atas, maka penulis bermaksud untuk melakukan studi tentang evaluasi terhadap kemampuan kader kesehatan dalam melakukan kegiatan penjangkauan.

\section{METODE PENELITIAN}

Jenis penelitian ini adalah Quasi Eksperimen tanpa pembanding. Penelitian dilakukan bulan Juni 2016 di di Desa Pageraji, Langgongsari, dan Rancamaya Kecamatan Cilongok Kabupaten Banyumas. Populasi dalam penelitian ini 50 kader, sedangkan pengambilan sampel dengan purposive sampling sebanyak 30 orang. Alur penelitian ini yaitu dari perijinan, pembuatan proposal, pengambilan data, dan pembuatan laporan akhir. Variabel Independen dalam penelitian ini adalah pendampingan. Sedangkan, Variabel dependen dalam penelitian ini adalah pengetahuan, sikap, dan keterampilan. Instrumen penelitian berupa kuesioner dan checklist Analisis data dengan untuk melihat perbedaan pretest dan posttest menggunakan uji Wilcoxon.

\section{HASIL DAN PEMBAHASAN}

Responden pada penelitian ini memiliki karakteristik sebagai berikut:

Tabel 1. Karakteristik responden penelitian

\begin{tabular}{cccc}
\hline & Variabel & Jumlah (orang) & Prosentase (\%) \\
\hline \multirow{4}{*}{ Umur } & $16-25$ tahun & 5 & 16,7 \\
& $26-35$ tahun & 10 & 33,3 \\
& $36-45$ tahun & 11 & 36,7 \\
& $46-55$ tahun & 4 & 13,3 \\
\hline \multirow{2}{*}{ Tingkat } & Total & 30 & 100 \\
pendidikan & Pendidikan Dasar & 20 & 66,7 \\
& Pendidikan Menengah & 9 & 30 \\
& & & \\
& Pendidikan Tinggi & 1 & 3,3 \\
\hline Masa kerja & Total & 30 & 100 \\
& Baru (<1 tahun) & 2 & 6,7 \\
& Sedang (1-3 tahun) & 4 & 13,3 \\
& Lama (>3 tahun) & 24 & 100 \\
\hline
\end{tabular}

Hasil analisis univariat berdasarkan karakteristik responden yaitu berdasarkan penggolongan umur responden, sebagian besar adalah 36-45 tahun sebanyak 11 orang $(36,7 \%)$. Penggolongan pendidikan formal responden, sebagian besar adalah pendidikan 
dasar sebanyak 20 orang $(66,7 \%)$. Penggolongan masa kerja responden, sebagian besar adalah lama ( > 3 tahun) sebanyak 24 orang $(80,0 \%)$.

Pengetahuan yang diukur dalam penelitian ini meliputi (1) kecelakaan kerja (2) pentingnya

Tabel 2. Kategori Pengetahuan perilaku aman (3) alat pelindung diri (APD). Berikut adalah gambaran kategori tingkat pengetahuan responden.

\begin{tabular}{ccccccc}
\hline Variabel & \multicolumn{2}{c}{ Baik } & \multicolumn{2}{c}{ Buruk } & \multicolumn{2}{c}{ Total } \\
\cline { 2 - 7 } Pengetahuan & $\mathrm{n}$ & $(\%)$ & $\mathrm{n}$ & $(\%)$ & $\mathrm{n}$ & $(\%)$ \\
\hline Pre Test & 16 & 53,3 & 14 & 46,7 & 30 & 100 \\
Post Test & 25 & 83,3 & 5 & 16,7 & 30 & 100 \\
\hline
\end{tabular}

Tabel 2. menunjukkan bahwa Sikap yang diukur dalam responden yang memiliki penelitian ini meliputi (1) peran pengetahuan baik pada saat pre test kader kesehatan (2) pemberdayaan sebanyak 16 orang $(53,3 \%)$. kader kesehatan (3) pendampingan Sedangkan responden yang memiliki pada kader kesehatan. Berikut adalah pengetahuan yang baik pada saat post test sebanyak 25 (83,3\%). gambaran kategori tingkat sikap responden:

Tabel 3. Kategori Sikap Responden

\begin{tabular}{ccccccc}
\hline Variabel Sikap & \multicolumn{2}{c}{ Baik } & \multicolumn{2}{c}{ Buruk } & \multicolumn{2}{c}{ Total } \\
\cline { 2 - 7 } & $\mathrm{n}$ & $(\%)$ & $\mathrm{n}$ & $(\%)$ & $\mathrm{n}$ & $(\%)$ \\
\hline Pre Test & 18 & 60,0 & 12 & 40,0 & 30 & 100 \\
Post Test & 12 & 40,0 & 18 & 60,0 & 30 & 100
\end{tabular}

Tabel 3. menunjukkan bahwa responden yang memiliki sikap baik pada saat pre test sebanyak 18 orang (60\%). Sedangkan responden yang memiliki sikap yang baik pada saat post test sebanyak 12 (40\%).

Keterampilan responden yang diukur pada saat penelitian meliputi (1) aspek sikap trainer (2) aspek kemampuan mengajar (3) aspek keterampilan mengajar (4) aspek kepribadian trainer. Berikut adalah gambaran kategori tingkat keterampilan responden: 
Tabel 4. Kategori Keterampilan Responden

\begin{tabular}{ccccccc}
\hline Variabel Sikap & \multicolumn{2}{c}{ Baik } & \multicolumn{2}{c}{ Buruk } & \multicolumn{2}{c}{ Total } \\
\cline { 2 - 7 } & $\mathrm{n}$ & $(\%)$ & $\mathrm{n}$ & $(\%)$ & $\mathrm{N}$ & $(\%)$ \\
\hline Pre Test & 0 & 0,0 & 30 & 100 & 30 & 100 \\
Post Test & 19 & 63,3 & 11 & 36,7 & 30 & 100 \\
\hline
\end{tabular}

Tabel 4. menunjukkan bahwa

responden yang memiliki keterampilan baik pada saat pre test sebanyak 0 orang $(0,0 \%)$. Sedangkan responden yang memiliki keterampilan yang baik pada saat post test sebanyak $19(63,3 \%)$.

Uji normalitas pada penelitian ini menggunakan uji statistik Saphiro-Wilk, dimana jika nilai $\mathrm{p}>\alpha(0,05)$, maka secara

\section{$\frac{\text { Post Test }- \text { Pre Test }}{\text { Pre Test }} \times 100 \%$}

Tabel 5. Hasil Uji Beda Pengetahuan Sebelum dan Sesudah Pendampingan

\begin{tabular}{ccccc}
\hline $\begin{array}{c}\text { Skor } \\
\text { Pengetahuan }\end{array}$ & Skor Rata-Rata & Nilai p & Simpulan & $\begin{array}{c}\text { Prosentase } \\
\text { peningkatan } \\
(\%)\end{array}$ \\
\hline Pre Test & 17,67 & 0,04 & $\begin{array}{c}\text { Ada Perbedaan } \\
\text { Pengetahuan }\end{array}$ & 2,26 \\
Post Test & 18,07 & & . & \\
\hline
\end{tabular}

Tabel 5. menunjukkan bahwa terdapat peningkatan nilai rata-rata pengetahuan responden sebelum dan sesudah pendampingan yaitu dari 17,67 menjadi 18,07. Berdasarkan hasil perhitungan dapat diketahui bahwa peningkatan nilai rata-rata skor pengetahuan antara pre statistik data tidak berdistribusi normal. Sedangkan, jika nilai $\mathrm{p}<\alpha$ $(0,05)$, maka secara statistik data berdistribusi normal. Uji beda pada penelitian ini menggunakan uji Wilcoxon karena data tidak berdistribusi normal. Peningkatan efektifitas dapat diukur dengan: 
Tabel 6. Hasil Uji Beda Sikap Sebelum dan Sesudah Pendampingan

\begin{tabular}{ccccc}
\hline Skor Sikap & Skor Rata-Rata & Nilai p & Simpulan & $\begin{array}{c}\text { Prosentase } \\
\text { peningkatan (\%) }\end{array}$ \\
\hline Pre Test & 15,40 & 0,00 & Ada Perbedaan Sikap & 5,19 \\
Post Test & 16,20 & & & \\
\hline
\end{tabular}

Tabel 6. menunjukkan bahwa terdapat peningkatan nilai rata-rata sikap responden sebelum dan sesudah pendampingan yaitu dari 15,20 menjadi 16,20. Berdasarkan hasil perhitungan dapat diketahui bahwa peningkatan nilai rata-rata skor sikap antara pre test dan post test yaitu sebesar 0,8 (5,19\%). Hasil uji statistik dengan menggunakan uji Wilcoxon diperoleh nilai $\mathrm{p}=0,00<\alpha$ $(0,05)$, artinya secara statistik menunjukkan ada perbedaan sikap yang signifikan sebelum dan sesudah pendampingan.

Tabel 7. Hasil Uji Beda Keterampilan Sebelum dan Sesudah Pendampingan

\begin{tabular}{ccccc}
\hline $\begin{array}{c}\text { Skor } \\
\text { Keterampilan }\end{array}$ & Skor Rata-Rata & Nilai p & Simpulan & $\begin{array}{c}\text { Peningkatan } \\
(\%)\end{array}$ \\
\hline Pre Test & 0,00 & 0,00 & $\begin{array}{c}\text { Ada Perbedaan } \\
\text { Keterampilan }\end{array}$ & $20,57 \%$ \\
Post Test & 20,56 & & The & \\
\hline
\end{tabular}

Tabel 7. menunjukkan bahwa terdapat peningkatan nilai rata-rata keterampilan responden sebelum dan sesudah pendampingan yaitu dari 0,00 menjadi 20,56. Berdasarkan hasil perhitungan dapat diketahui bahwa peningkatan nilai rata-rata skor keterampilan antara pre test dan post test yaitu sebesar $20,57 \%$. Hasil uji statistik dengan menggunakan uji Wilcoxon diperoleh nilai $\mathrm{p}=0,00<\alpha$ $(0,05), \quad$ artinya secara statistik menunjukkan ada perbedaan keterampilan yang signifikan sebelum dan sesudah pendampingan. 
Tabel 8. Rekapitulasi Perbedaan Pengaruh Safety Behavior Terhadap Pengetahuan, Sikap, dan Keterampilan Sebelum dan Sesudah Pendampingan

\begin{tabular}{lllllll}
\hline No & Variabel & $\begin{array}{c}\text { Mean } \\
\text { Pretest }\end{array}$ & $\begin{array}{c}\text { Mean } \\
\text { Posttest }\end{array}$ & $\begin{array}{c}p \text { - } \\
\text { value }\end{array}$ & Efektifitas & Keterangan \\
& & 17,67 & 18,07 & 0,04 & $2,26 \%$ & Ada perbedaan \\
1 & Pengetahuan & 17,04 & 16,20 & 0,00 & $5,19 \%$ & Ada perbedaan \\
2 & Sikap & 15,20 & 20,57 & 0,00 & $20,57 \%$ & Ada perbedaan \\
\hline
\end{tabular}

Tabel 4.10 menunjukkan bahwa setiap variable terdapat perbedaan setelah adanya intervensi pendampingan. Namun, variable yang paling berpengaruh yaitu variable keterampilan, hal ini ditunjukkan dengan nilai efektifitas sebesar $20,57 \%$.

Berdasarkan tabel 5 menunjukkan bahwa hasil uji Wilcoxon diperoleh nilai $\mathrm{p}=0,04(<$ 0,05), artinya secara statistik menunjukkan ada perbedaan pengetahuan yang signifikan sebelum dan sesudah pendampingan. Hal ini sesuai dengan penelitian Amir (2008) mengenai pengaruh penyuluhan model pendampingan terhadap perubahan status gizi anak usia 6-24 bulan bahwa adanya peningkatan skor rata-rata pengetahuan. Hasil penelitian juga selaras dengan penelitian yang dilakukan Retnawati $d k k$ (2014) bahwa terdapat peningkatan pengetahuan kader pendamping setelah pelaksanaan metode simulasi terhadap keberhasilan penerapan makan yang beraneka ragam. Hasil penelitian juga selaras dengan penelitian yang dilakukan Ariyani (2014) bahwa pembinaan kader kepada wanita pekerja seks (WPS) memberikan pengetahuan lebih baik kepada para WPS terkait pembinaan kesehatan, melakukan pemeriksaan setiap minggunya, memberikan pengamanan untuk para WPS dalam melakukan hubungan.

Hasil penelitian menunjukkan terdapat peningkatan pengetahuan responden sebesar 0,4 (2,26\%), yang ditandai dengan kenaikan nilai ratarata skor pengetahuan pada saat pre test 17,67 meningkat menjadi 18,07 pada saat post test. Hasil penelitian ini sesuai dengan penelitian Rahmayanti (2010) yang dilakukan di RSUD Cibanat Cimahi Kabupaten bandung yaitu ada perbendaan yang signifikan rata-rata nilai pengetahuan ibu tentang perawatan metode 
kanguru sesudah pendidikan kesehatan dengan metode pendampingan. Hasil penelitian ini juga selaras dengan penelitian Jelita (2014) bahwa terdapat peningkatan pengetahuan anak dalam memelihara kesehatan gigi dan mulut setelah dilakukan penyuluhan dengan metode demonstrasi.

Berdasarkan tabel 6 menunjukkan bahwa hasil uji statistik dengan menggunakan uji Wilcoxon diperoleh nilai $\mathrm{p}=0,00(<$ 0,05), artinya secara statistik menunjukkan ada perbedaan sikap yang signifikan sebelum dan sesudah pendampingan. Hal ini sesuai dengan penelitian Riyantini (2010) yang dilakukan di RSAB Harapan Kita Jakarta tentang pengaruh pendidikan kesehatan terhadap sikap responden meningkat setelah pendidikan kesehatan dengan metode ceramah dan demonstrasi. Hasil ini juga selaras dengan penelitian Kinasih (2012) bahwa terdapat hubungan sikap dengan motivasi kesembuhan pasien lanjut usia setelah dilakukan pendampingan spiritual. Hasil ini juga selaras dengan penelitian Artadana (2015) bahwa terdapat peningkatan sikap dan motivasi belajar dan hasil belajar pada mata pelajaran Ilmu Pengetahuan Alam kelas x Sekolah Mengah Atas Luar Biasa C1 Negeri Denpasar setelah pembelajaran melalui metode demonstrasi berbantuan CD interaktif. Hasil ini juga selaras dengan penelitian Dwiatmoko (2011) bahwa ada perbedaan bermakna nilai kebersihan gigi tiruan lepasan (GTL) antara kelompok kontrol dan perlakuan sesudah komunikasi kesehatan dengan metode ceramah.

Hasil penelitian menunjukan terdapat peningkatan nilai rata-rata sikap responden sebasar 0,8 $(5,19 \%)$, yang ditandai dengan kenaikan nilai rata-rata skor sikap pada saat pre test 15,20 meningkat menjadi 16,20 pada saat post test. Hasil ini sesuai dengan penelitian Jumiyati (2014) bahwa terdapat peningkatan rerata sikap kader dalam upaya pemberian ASI eksklusif setelah dilakukan pendampingan dengan media modul.

Berdasarkan tabel 7
menunjukkan bahwa hasil uji
statistik dengan menggunakan uji
Wilcoxon diperoleh nilai $\mathrm{p}=0,00(<$
$\begin{array}{llr}0,05), \text { artinya } & \text { secara } & \text { statistik } \\ \text { menunjukkan ada } & \text { perbedaan } \\ \text { keterampilan yang } & \text { signifikan }\end{array}$


sebelum dan sesudah pendampingan.

Hasil ini sesuai dengan penelitian

Merdiana

tentang

keterampilan posyandu sebelum dan

sesudah pendampingan yang menunjukkan bahwa ada perbedaan keterampilan kader dalam pengukuran antropometri sebelum dan sesudah pendampingan di wilayah kerja Puskesmas Taruh, Kabupaten Tegal. Hasil ini juga selaras dengan penelitian Agustin (2012) di Palembang yaitu ada perbedaan yang signifikan rata-rata skor keterampilan kader tentang perawatan metode kanguru sesudah pelatihan dengan metode demonstrasi. Hasil ini juga selaras dengan hasil penelitian Milwati (2015) bahwa terjadi peningkatan rerata keterampilan pemeriksaan payudara sendiri (SADARI) oleh ibu-ibu PKK sesudah dilakukan pendidikan dan demonstrasi SADARI.

Berdasarkan tabel 8 menunjukkan bahwa keterampilan merupakan variable yang paling berpengaruh dengan peningkatan 20,57\%. Hasil ini sesuai dengan penelitian Marjan (2014) bahwa pengaruh pembelajaran pendeketan saintifik terhadap keterampilan proses belajar sains mengalami peningkatan 73,93 dengan kategori tinggi.

\section{KESIMPULAN}

1. Karakteristik responden berdasarkan usia, sebagian besar adalah 36-45 tahun sebanyak 11 orang (36,7\%). Penggolongan pendidikan formal responden, sebagian besar adalah pendidikan dasar sebanyak 20 orang $(66,7 \%)$. Sedangkan penggolongan masa kerja responden, sebagian besar adalah lama ( > 3 tahun) sebanyak 24 orang $(80,0 \%)$.

2. Pengetahuan kader tentang safety behavior sebelum diberikan pendampingan yaitu kader pengetahuan buruk 14 orang $(46,7 \%)$ dan kader pengetahuan baik 16 orang (53,3\%). Sedangkan, pengetahuan kader sesudah diberikan pendampingan yaitu kader pengetahuan buruk lima orang $(16,7 \%)$ dan kader pengetahuan baik 25 orang $(83,3 \%)$.

3. Sikap kader tentang pentingnya peran kader sebelum diberikan pendampingan yaitu sikap kader 
buruk 12 orang (40\%) dan sikap kader baik 18 orang $(60 \%)$. Sedangkan, sikap kader sesudah diberikan pendampingan yaitu sikap kader buruk 18 orang $(60 \%)$ dan sikap kader baik 12 orang $(40 \%)$.

4. Keterampilan kader tentang penyampaian informasi safety behavior sebelum diberikan pendampingan yaitu keterampilan kader buruk 30 orang $(100 \%)$ dan keterampilan kader baik 0 orang $(0 \%)$. Sedangkan, keterampilan kader sesudah diberikan pendampingan yaitu keterampilan kader buruk 11 orang $(36,7 \%)$ dan keterampilan kader baik 19 orang $(63,3 \%)$.

5. Hasil analisis uji statistik Wilcoxon menunjukkan adanya peningkatan pengetahuan, sikap dan keterampilan yang signifikan sesudah pendampingan, dengan hasil analisis pengetahuan nilai $\mathrm{p}$ $=0,04<\alpha(0,05)$, hasil analisis sikap nilai $\mathrm{p}=0,00<\alpha(0,05)$, hasil analisis keterampilan $\mathrm{p}=$ $0,00<\alpha(0,05)$.

6. Terdapat pengaruh safety behavior terhadap pengetahuan, sikap, dan keterampilan.

Efektifitas pengetahuan yaitu $2,26 \%$, efektifitas sikap yaitu $5,19 \%$, dan efektifitas keterampilan yaitu $20,57 \%$. Sehingga, variable yang paling berpengaruh yaitu keterampilan.

\section{SARAN}

1. Bagi Kader Kesehatan

a. Kader kesehatan supaya tetap belajar dan memahami materi pendampingan supaya pengetahuan kader kesehatan semakin meningkat.

b. Kader kesehatan supaya memahami dan merespon materi pendampingan supaya sikap kader semakin meningkat.

c. Kader kesehatan supaya aktif melakukan penyuluhan informasi safety behavior kepada penderes kelapa supaya keterampilan kader semakin meningkat.

2. Bagi Peneliti

Peneliti yang melakukan penelitian lebih lanjut supaya mencari variable-variabel lain yang lebih efektif untuk mengurangi risiko kecelakaan kerja penderes, seperti 
pemantauan secara langsung safety behavior pada penderes kelapa dan penggunaan alat pelindung diri.

\section{DAFTAR PUSTAKA}

Agustin, 2012, Efektifitas Pelatihan Metode Kanguru terhadap Pengetahuan dan Keterampilan Kader Kesehatan di Wilayah Kerja Puskesmas Gandus Palembang, Skripsi, Poltekkes Kemenkes Palembang.

Aji, B., Ulfah, N., Masfiah., Harwanti, 2015, Extending Social Health Protection to Informal Sector in Indonesia: How to Enroll Palm Suga Farmers in National Health Insurance, Laporan Penelitian International Research Collaboration Grant (IRC UNSOED) tahun 2015, Purwokerto.

Ariyani, N., Yusuf, A., 2014, Peranan Kader Kesehatan dalam Pembinaan Wanitas Pekerja Seks (WPS) di Lokalisasi Sunan Kuning, Journal of Non Formal Education and Community Empowerment, NFECE 3 (2).

Dwiatmoko, S., Kristiana, D., 2011, Pengaruh Komunikasi Kesehatan secara Lisan dan Tulisan terhadap Pengetahuan, Sikap dan Kebersihan Gigi Tiruan Para Pemakai Gigi Tiruan Lepasan, Dentika Dental
Journal, Vol 16, No. 1, 1417, 2011.

Jelita, F., Hiola, R., Pakaya, Wahab., 2014, Pengaruh Penyuluhan terhadap Pengetahuan Anak dalam Memelihara Kesehatan Gigi dan Mulut di Kelas IV SD N 1 Limboto, Jurnal KIM Fakultas Ilmu-Ilmu Kesehatan dan Keolahragaan, Volume 2, No. 3, 2014.

Jumiyati, Nugrahaeni, S,A., Margawati, A., 2014, Pengaruh Modul terhadap Peningkatan Pengetahuan, Sikap dan Praktek Kader dalam Upaya Pemberian Asi Eksklusif, Jurnal Gizi Indon, 37(1):19-28, 2014.

Marjan, J., Arnyana, P., Setuawan, N., 2014, Pengaruh Pembelajaran Pendekatan Saintifik Terhadap Hasil Belajar Biologi dan Keterampilan Proses Sains Siswa MA Mu'allimat NM Pancor Selong Kabupaten Lombok Timur Nusa Tenggara Barat, e-Jurnal Program Pascasarjana Universitas Pendidikan Ganesha, Volume 4, 2014.

Milwati, S., Hadi, S., Utami, N, W., 2015, Penerapan Promosi Kesehatan Metode Demonstrasi dan Keterampilan Pemeriksaan Payudara Sendiri (SADARI) bagi Ibu-Ibu PKK di Kota Malang, Jurnal Informasi Kesehatan Indonesia (JIKI), Volume 1, No.2, 142-147, November 2015. 
Notoatmodjo, S., 2003, Ilmu Kesehatan Masyarakat, Rhineka Cipta, Jakarta.

Rahmayanti, S., 2010, Pengaruh Perawatan Metode Kanguru Terhadap Pengetahuan dan Sikap Ibu dalam Merawat BBLR di RSUD Cibanat Cimahi, Tesis, Fakultas Ilmu Keperawatan Program Pasca sarja Universitas Indonesia Kekhususan Keperawatan Anak Depok.

Ramli, S., 2009, Sistem Manajemen Keselamatan dan Kesehatan Kerja, Dian Rakyat, Jakarta.

Retnawati, S, A., Widajanti, L., Nugrahaeni, S,A., 2014, Pengaruh Pelatihan dengan Metode Simulasi Terhadap Keberhasilan Penerapan Makan Beraneka Ragam oleh Kader Pendamping (Studi di Kecamatan Trawas Kabupaten Mojokerto, Jurnal Manajemen Kesehatan Indonesia, Volume 02, No. 03, Desember 2014.

Riyantini, R, 2010, Pengaruh Pendidikan Kesehatan terhadap Pengetahuan, Sikap dan Keterampilan Ibu serta Kejadian Hiperbilirubinemia pada Bayi Baru Lahir di RSAB Harapan Kita Jakarta, Tesis, Program Pascasarjana FIK UI.

Shiddiq, S., Wahyu, A., Muis, M., 2013, Hubungan Persepsi K3 Karyawan dengan Perilaku Tidak Aman di bagian Produksi Unit IV PT. Semen Tonasa Tahun 2013, Skripsi, Jurusan Kesehatan Masyarakat, Universitas Hasanudin.

Utami, P., Sahar, J., dan Widyatuti, 2015, Pengaruh Pemberdayaan Kader dalam Penerapan Kartu Pemantauan Mandiri (KPM) terhadap Pencegahan Gangguan Pergerakan Akibat Asam Urat pada Lansia, Coping Ners Journal, Vol 3, No. 3, 2015. 